\title{
A COMPARATIVE STUDY ON THE PERFORMANCE OF NIFTY 5O AND EQUITY FUNDS UNDER TIER-II OF NATIONAL PENSION SCHEME
}

\author{
Dr. Baneshwar Kapasi ${ }^{1}$, Miss. Saroj Mahato ${ }^{2}$ \\ ${ }^{1}$ Associate Professor, Department of Commerce, Kazi Nazrul University, Asansol Paschim \\ Bardhhaman, West Bengal, Pin - 713340 \\ ${ }^{2}$ Research scholar, Department of Commerce, Kazi Nazrul University and SACT, Banwarilal Bhalotia \\ College, Asansol Paschim Bardhhaman, West Bengal, Pin-713303
}

Article DOI: https://doi.org/10.36713/epra9325 DOI No: 10.36713/epra9325

\begin{abstract}
The National Pension Scheme (NPS) is a defined contribution and a corporate pension fund that provides financial assistance to all Indian citizens. There are two types of accounts in the National Pension Scheme: Tier I and Tier II. Tier I is a mandatory deposit pension fund account and Tier II is a voluntary pension account. Tier I and Tier II is are consisted of different assets namely, equity, government security and alternative asset. The equity schemes are directly linked with the market. The return of all the fund managers in equity schemes are not same as the portfolio of all the fund managers are not same.

Secondary data has been collected from respective websites of Pension Fund Managers and has been used to calculate mean, SD, Variance, and Correlation to predict the performance of equity funds. ANOVA and T-test have been for assessing the comparative analysis of the different fund managers under equity scheme in tier II.

As per the study, LIC PF and ICICI PF are the best performer during the study period. The performance of SBI $P F$ is poor among other equity funds under Tier-II of NPS during the study period. In term of risk, LIC PF is the higher risky equity fund and UIT PF is the lowest risky equity fund under Tier-II of NPS. It can be said that investors need to be high-risk taker to invest in that LIC PF.

Through the risk analysis during said period of time, it is found that the ability to observe risk differs in equity funds under Tier-II of NPS. The main reason for this being a voluntary account of Tier-II. As there is no lock-in period in this account, the investors mostly use for a short-term purpose. In the recent decision of the government, Tier-II offers a lock-in period for 3 years with tax benefit. This decision may be affected the investment pattern of the investors.
\end{abstract}

KEY WORDS: - National Pension Scheme, Performance, Equity Scheme, Nifty 50

\section{INTRODUCTION}

People go through many stages in their lives. They are dealing with a variety of concerns in our society, including health issues, mental health issues, financial issues, family issues, and housing issues, among others. The report of AGE-WELL FOUNDATION revealed that the majority of older persons face financial hardship in old age as most of them are not in a position to earn their livelihood in India.

It is vital for everyone to have a financially secure existence in their later years. Retirement planning is the process of preparing to provide financial assistance to elderly persons after they retire. There are a variety of retirement planning options available, including gratuity, provident funds, mutual fund investments, fixed deposits, and pension funds, among others. One of the most significant tools for retirement planning is a pension.

Pension may be two of types, namely pension for employee of an organisation and pension of the general people. Social security pension schemes may be two types, namely defined contribution and defined benefits. India is the second largest developing country in terms of population. The percentage of organised in formal sector is less than ten percent. 
To control the financial pressure from government and to provide old age security to all section of people, the Central Government introduced the "National Pension Scheme (NPS)" as a new pension system on January 1, 2004. With effect from May 1, 2009, this system was voluntarily expanded to all citizens of the country, including self-employed professionals and the unorganized sector.

\section{BASIC STRUCTURE OF NATIONAL PENSION SYSTEM}

The NPS has two tier, tier-I and tier-II. Tier I is essential for opening tier-II account. Tier I account is also known as pension account. It has a Permanent Retirement Account Number (PRAN) which has a tenure period until the age of 60 of subscribers. The subscribers able to extend the investment until the age of 70 as a maturity period. The withdrawal benefits are available under Tier I account. On withdrawal up to first $40 \%$ of the NPS Tier I account is tax-free. Another $40 \%$ used to buy as annuity and remaining $20 \%$ can either be withdrawn after paying tax. Under National Pension System investment made in Tier I provide tax benefit up to Rs. 1.5 lakhs under section 80C and additional Rs. 50,000 under section 80 CCD (1B) of Income Tax Act 1961.

Tier II account was launched by the government in the year 2009 and it offers greater flexibility than Tier I account. It is a saving account there is no minimum and maximum limit to invest in Tier II of National Pension Scheme but require to contribute initial amount of Rs.1000 to active account. There is no lock-in period but the Government employees able for 3 years lock-in facilities which provide tax benefits from December 2018 .

Point of Presence (POP) or Point of Presence Service Providers (POP-SPs): - Point of Presence is the first interaction point between NPS subscriber and the NPS architecture. Point of Presence Service Providers (POPSPs) is the registered and authorized branches of a POP, includes any nearest branch of public bank and private bank.

Central Recordkeeping Agency (CRA): - The National Securities Depository Limited (NSDL) serves as the NPS's central recordkeeper, performing recordkeeping, administration, and customer service functions for all subscribers. Each account holder receives a Permanent Retirement Account Number (PRAN) in order to maintain all databases and record transactions.

Pension Fund Managers (PFMs): - Fund managers are a set of experts who are capable of professionally manage funds invested by the investors. In National Pension Scheme, there are 8 different PFMs, having four classes i.e., Equity (E ), Corporate debt Class(D), Government bond (B), Alternative investment(A). The subscriber has an option to select any PFMs to invest their money. Pension Fund Managers under National Pension Scheme: -

1. SBI Pension Fund Private Limited

2. UTI Retirement Solutions Limited

3. LIC Pension Fund Limited

4. Kotak Mahindra Pension Fund Limited

5. ICICI Prudential Pension Funds Management Company Limited

6. HDFC Pension Management Company Limited

7. Birla Sunlife Pension Management Limited

8. Reliance Capital Pension Fund Limited

Trustee Bank: - Trustee Bank is responsible to provide banking facilities to subscribers of the National Pension Scheme. It acts as an intermediary between Nodal officers to Pension fund. It receives funds from Nodal officers posted in different POPs and verifies the received amount with the amount as per the Subscriber Contribution File (SCF) uploaded by the Nodal office on the CRA system and then transfers the funds to the selected PFMs for investment.

Custodian: - It acts as a Custodian of securities in physical form and depository participant for securities in Demat mode in the National Pension Scheme. The Pension Fund Regulatory and Development Authority (PFRDA) has appointed Stock Holding Corporation of India Ltd. (SCHIL) to ensure their services as "The Custodian and Depository Participant" under National Pension Scheme.

NPS Trust: - National Pension System Trust was established on 1882 by Pension Fund Regulatory and Development Authority for preserving of assets and funds under the NPS and safeguard the invest of the subscribers. 
Pension Fund Regulatory and Development Authority (PFRDA): - The Pension Fund Regulatory and Development Authority was regulatory body established through a resolution by the Bank of India to promote, develop and regulate pension sector in India for providing financial security to the people after retirement on a sustainable basis.

Annuity Service Providers (ASPs): - Annuity Service Provider is a registered insurance company through Pension Fund Regulatory Development Authority for providing of annuity services to subscribers of the National Pension System after attains the age of 60.

Subscriber: - All Indian citizens are eligible to open their account under National Pension Scheme, between the group of 18-65. Special rules are applied to the person who wants to open their account after the age of 60.

Investment Options: - Subscribers have options to choose any one of the Pension Fund Managers (PFMs) appointed under NPS to manage their investments. There are two following options provided to the subscribers:

Active Choice Option: - Under this option, Subscriber gets the independence to choose their asset allocation among equity, Corporate Bonds, Government securities and Alternative securities. The corporate Bond and Government Securities is wholly available to the subscriber to invest but investment in Equity is restricted to $50 \%$ of contribution amount.

Auto Choice Option: - In this option, there are three choices which is predefined spread of funds in Equity, Corporate Bond, and Government. It is also known as 'Life Cycle Fund' where subscribers allow to change their choice to reduce risk and increase return pattern. Depending upon the risk appetite, three different option available within Auto choice.

Charges: - The charges for initial subscription and contribution are Rs. 100 plus $0.25 \%$ of contribution subject to minimum Rs.20 and maximum Rs. 25,000. Central Recordkeeping Agency (CRA) charges Rs. 50 at the time of opening a Permanent Retirement Account including annual maintenance charge of Rs.225. Trustee bank changes on transaction refer to the whole chain of activities from instructions received by subscribers to transfer of funds to the designated PFMs and changing amount is between zero to Rs.15. Investment Management Fee charged by Pension Fund Managers which includes all transaction related charges such as brokerage, transaction cost etc. except custodian charges and taxes. Asset Servicing Charges taken by Custodian for Demat account, Receipt of shares and SEBI charges through deduction of Net Asset Value.

\section{LITERATURE REVIEW}

K Seethal \& B Meneka (2018) have conducted a study on the structure and philosophy of the National Pension Scheme. They have concluded in their study that individuals with little or no expertise of the financial markets can simply access NPS.

S. Ramesh (2017) has conducted a study on NPS for Salem and Erode districts. He has used primary data using personal interviews and questionnaire. He has used T-test, ANOVA and percentage analysis to arrive at a valid conclusion. It has been revealed from the study that if employees are constantly reminded of pension policies, there is a lot of room for them to invest in pension plans. It is essential to conduct awareness activities among private employees in order to offer proper knowledge regarding pension plans.

Subhro Sen Gupta, Neha Gupta and Komal Garg (2017) have conducted a study on National Pension Scheme to study the relationship among equities, corporate bonds, and government securities between Tier 1 and Tier 2. It has been discovered that the general public has a higher level of trust in government securities.

M. K. Kurmi, B. Kapasi, and R.K. Paswan (2020) have conducted a study on NPS to compare the performance of different schemes in NPS. It has been discovered that the average return on NPS Tier II funds is higher than the average return on NPS Tier I funds. The risk of a fund in Tier-II is smaller than that of a fund in Tier I.

G Apriyanto et all. (2016) investigated the performance of Pension Fund A, Pension Fund B, and Pension Fund $C$ through classical theory. Gathering data by making actual observations in the field at any given time. The Pension Fund A is good in terms of performance assessment, but the hegemony and domination of the employer and the board of trustees are fairly high, resulting in the damage of the pension fund's interests in the form of delays in raising pension benefits.

S. Saini, and D. Shimar (2017) have conducted a study to analyze return of mutual funds and national pension scheme. Comparison is done with the help of secondary data. In NPS, investor gets limited asset classes to choose but in mutual fund, there are vast array of assets classes. Mutual funds highly liquid investment in comparison to National Pension Fund. NPS tends to be more suitable for the conservative investors who don't prefer taking more than average risks. 


\section{RESEARCH GAP}

From the previous review it is seen that few studies have been carried out for measuring the financial performance of the National Pension System. But there is no specific research has been conducted for measuring the performance of equity scheme under Tier-II of NPS in comparison of Nifty 50.

\section{OBJECTIVES OF THE STUDY}

1) To assess the performance of fund under scheme-E in Tier-II of NPS.

2) To compare the performance of fund under scheme-E in Tier-II of NPS with the performance of NIFTY 50

\section{RESEARCH QUESTIONS}

(1) Are all the funds under Scheme-E in Tier-II of NPS successful in delivering comparative return?

(2) Are the funds under the Scheme-E in Tier-II of NPS can provide a return higher than market return (Nifty50)?

(3) Are the all funds under the Scheme-E have same risk?

(4) Are the risks of funds under the scheme-E of Tier-II in NPS is greater than the risk of Nifty 50 ?

\section{HYPOTHESIS OF THE STUDY}

\section{Hypothesis 1:}

H0: There is no significant difference in return among the funds under Scheme Equity in Tier-II of NPS

H1: There is a significant difference in return among the funds under Scheme Equity in Tier-II of NPS

\section{Hypothesis 2:}

H0: There is no significant difference in the return of the funds under Scheme Equity in Tier-II and Nifty 50

H1: There is a significant difference in the return of the funds under Scheme Equity in Tier-II and Nifty 50

\section{Hypothesis 3:}

H0: There is no significant difference of risk among the funds under the Scheme Equity in Tier-II.

H1: There is a significant difference of risk among funds under the Scheme Equity in Tier-II.

\section{Hypothesis 4:}

H0: There is no significant difference in the risk of the funds under Scheme Equity in Tier-II and Nifty 50 H1: There is a significant difference in the risk of the funds under Scheme Equity in Tier-II and Nifty 50

\section{RESEARCH METHODOLOGY}

Data Collection - Secondary Data has been collected from the website of respective PFMs of Scheme-E under Tier-II. The closing value of Nifty 50 has been collected form the official website of NSE. In this study, six funds of the equity scheme are considered to predict the performance of equity funds under Tier II. These funds are SBI Pension Funds Pvt. Ltd. (Inception Date-14/12/2009), ICICI Pru Pension Fund Mgmt. Co. Ltd. (Inception Date-21/12/2009), UTI Retirement Solutions Ltd. (Inception Date-14/12/2009), Kotak Mahindra Pension Fund Ltd. (Inception Date-14/12/2009), HDFC Pension Management Co. Ltd. (Inception Date01/08/13), and LIC Pension Fund Ltd. (Inception Date-12/08/13). The reason behind the selection of such funds is that all these six funds are available to provide data for last five years.

Statistical Tools and Techniques - The risk and return of funds under equity schemes under Tier-II and Nifty 50 have been calculated. Descriptive statistics like Mean, Variance, Standard Deviation, Correlation, and inferential statistics T-test and ANOVA have been used in this study.

\section{Calculation of Return}

For Nifty50,

$$
R_{p}=\left(\frac{P_{t}}{P_{t-1}}\right)-1
$$

Where $P_{t}=$ closing price of fund Nifty 50 on date $\mathrm{t}$

$P_{t-1}=$ opening price of fund Nifty to on date $\mathrm{t}-1$

For Tier-E(II),

$R_{T-I I}=\left(\frac{N A V_{2}}{N A V_{1}}\right)-1$ 
on date $\mathrm{t}$

Where, $N A V_{2}=$ Closing net asset value (NAV) of funds under equity scheme in Tier-II of NPS on date $\mathrm{t}-1$

$$
N A V_{1}=\text { Closing net asset value(NAV) funds under equity scheme in Tier-II of NPS }
$$

Daily returns are multiple by 100 to express in percentage.

\section{Calculation of annualised of return}

For Nifty50,

$$
\bar{R}_{p}=\frac{\sum R_{p}}{n} \times 365 \text { days }
$$

Where, $n=$ Number of observations

$\Sigma=$ summation of observation

$R_{p}=$ Value of the return

For Tier- E(II) of NPS,

$$
\bar{R}_{T-I I}=\frac{\Sigma R_{T-I I}}{n} \times 365 \text { days }
$$

Where, $n=$ Number of observations

$$
\Sigma=\text { summation of observation }
$$

$R_{T-I I}=$ Value of the return on equity funds under Tier-II of NPS

\section{Calculation of annualized variance of return}

$$
\text { For Nifty } 50 \text {, }
$$

Variance $=\frac{\Sigma\left(R_{p}-\overline{R_{p}}\right)^{2}}{n-1} \times 365$ days

Where, $\Sigma=$ summation of observation

$R_{p}=$ Value of the return on Nifty 50

$\bar{R}_{p}=$ mean value of return on Nifty 50

$n=$ number of observationscase

For Tier-E(II) of NPS,

Variance $=\frac{\Sigma\left(R_{T-I I}-\bar{R}_{T-I I}\right)^{2}}{n-1} \times 365$ days

Where, $\Sigma=$ summation of observation

$R_{T-I I}=$ Value of the return on equity funds under Tier-II of NPS

$\bar{R}_{T-I I}=$ yearly mean return on equity funds under Tier-II of NPS $n=$ number of observations

Calculation of SD of Return: -

For NIFTY50

Standard Deviation $\left(\sigma_{p}\right)=\sqrt{\frac{\sum\left(R_{p}-\overline{R_{p}}\right)^{2}}{n-1}}$

Where, $\Sigma=$ summation of observation

$R_{p}=$ Actual return of NIFTY50

$\overline{\mathrm{R}}_{\mathrm{p}}=$ yearly mean value of return on NIFTY50

$\mathrm{n}=$ number of observations

For equity return of NPS,

Standard Deviation $\left(\sigma_{N A V}\right)=\sqrt{\frac{\sum\left(R_{N A V}-\bar{R}_{N A V}\right)^{2}}{n-1}}$ 
Where, $\Sigma=$ summation of observation

$R_{T-I I}=$ Return on equity funds under Tier-II of NPS

$\overline{\mathrm{R}}_{\mathrm{T}-\mathrm{II}}=$ yearly mean value of return on equity funds under Tier-II of NPS

$\mathrm{n}=$ number of observations

\section{DISCUSSION OF RESULT}

Table 1 depicts the average annualized daily return of Nifty 50 and funds under scheme equity in TierE(II) of NPS for the period of 2016 to 2020. The average annualized daily returns of SBIPF, ICICIPF, UTIPF, KotakPF, HDFCPF, and LICPF are 21.72\%, 16.47\%, 24.32\%, 16.77\%, 17.51\%, $17.74 \%$, and $36.20 \%$ respectively. The Nifty 50 has a $21.72 \%$ average annualized daily return during the study period. As per the above table it is seen that ICICIPF and LICPF are two such equity funds which earn more return than return of Nifty 50. LIC equity fund has achieved the highest return whereas SBIPF equity fund has shown the lowest average return for the study period. To make a year-wise comparison between Nifty 50 and all other equity funds under Tier-(II) of NPS, a chart has been drawn as below.

Table 1

Annualized daily return of Nifty 50 and Funds under Scheme Equity in Tier- E(II) of NPS Table1: Annualized daily return of Nifty50 and Tier- E(II) of NPS (in percentage)

\begin{tabular}{|l|l|l|l|l|l|l|}
\hline \multicolumn{7}{|c|}{ Yable1: Annualized daily return of Nifty50 and Tier- E(II) of NPS } \\
(in percentage) \\
\cline { 2 - 7 } Fund & \multicolumn{7}{|c|}{ Years } & \multirow{2}{*}{ Average } \\
\cline { 2 - 7 } & 2020 & 2019 & 2018 & 2017 & 2016 & 21.72 \\
\hline Nifty av50 & 26.27 & 19.46 & 5.79 & 37.68 & 5.75 & 16.47 \\
\hline SBIPF & 36.84 & 11.24 & 3.16 & 25.22 & 7.72 & 24.32 \\
\hline ICICIPF & 27.99 & 17.46 & 2.81 & 39.06 & 9.58 & 16.77 \\
\hline UTIPF & 17.77 & 10.23 & 3.48 & 27.07 & 6.46 & 17.51 \\
\hline KotakPF & 20.10 & 12.69 & -1.76 & 30.07 & 4.95 & 17.74 \\
\hline HDFCPF & 29.61 & 18.37 & 4.03 & 23.35 & 12.13 & 36.20 \\
\hline LICPF & 30.47 & 13.98 & 2.28 & 46.72 & 25.68 & \\
\hline
\end{tabular}

Source: Own computation

Table 2: Correlation of return of funds under scheme equity in Tier II of NPS and return of Nifty50

\begin{tabular}{|l|l|}
\hline SBIPF & 0.79 \\
\hline ICICIPF & 0.98 \\
\hline UTIPF & 0.98 \\
\hline KotakPF & 0.98 \\
\hline HDFCPF & 0.82 \\
\hline LICPF & 0.79 \\
\hline
\end{tabular}

Table 2 exhibits the degree of relationship in annualized daily return between Nifty 50 and the returns of the funds under scheme equity in Tier-II of NPS. From the above table it is seen that ICICIPF, UTIPF, and KotakPF have a high degree of positive relationship relationship with Nifty50 whereas SBIPF and LICPF have a low degree of relationship with Nifty 50 during the said period. 
Table 3: Variance of return of Nifty 50 and funds under scheme equity Tier- E(II) of NPS (in percentage)

\begin{tabular}{|c|c|c|c|c|c|c|}
\hline \multirow[t]{2}{*}{ Fund } & \multicolumn{5}{|l|}{ Year } & \multirow[t]{2}{*}{ Average } \\
\hline & 2020 & 2019 & 2018 & 2017 & 2016 & \\
\hline Nifty50 & 14.07 & 2.75 & 2.40 & 1.18 & 3.33 & 4.74 \\
\hline SBIPF & 31.53 & 2.00 & 1.51 & 0.79 & 2.29 & 7.62 \\
\hline ICICIPF & 13.95 & 2.7 & 2.44 & 1.27 & 3.50 & 4.78 \\
\hline UTIPF & 8.82 & 2.03 & 1.68 & 0.88 & 2.16 & 3.11 \\
\hline KotakPF & 14.81 & 1.73 & 1.25 & 0.86 & 1.55 & 4.04 \\
\hline$H D F C P F$ & 13.85 & 2.82 & 2.51 & 1.94 & 3.48 & 4.92 \\
\hline$L I C P F$ & 24.52 & 5.30 & 4.26 & 23.02 & 35.58 & 18.53 \\
\hline
\end{tabular}

Source: Own Computation

Table 3 portrays the variability in annualized daily return of Nifty50 and all other equity funds under Tier-II of NPS. In the above table, the average annualized daily return of Nifty50 is 4.74 whereas LICPF has a higher return (i.e., 18.53) and UTIPF has a lower return which is 3.11. A chart is prepared to analyze the variability in annualized daily return between Nifty50 and other equity funds of Tier-II in NPS.

Table 4: Correlation of Variance of return of Nifty 50 and funds under scheme equity in Tier- E(II) of NPS

\begin{tabular}{l|l}
\hline SBIPF & 0.99 \\
\hline$I C I C I P F$ & 1.00 \\
\hline UTIPF & 1.00 \\
\hline KotakPF & 0.99 \\
\hline$H D F C P F$ & 1.00 \\
\hline LICPF & 0.27
\end{tabular}

Table 4 shows the correlation between Nifty 50 and equity funds under Tier-II of NPS in the variability of daily return from 2016 to 2020. During the study period, there was a perfect correlation of ICICIPF, UTIPF, and HDFCPF with Nifty50 while its relationship is low with LIC (i.e., 0.27).

\section{TESTING OF HYPOTHESIS}

Hypothesis (1) H0: There is no significant difference in return among equity funds under Tier-II of NPS HI: There is a significant difference in return among equity funds under Tier-II of NPS 
ANOVA

\begin{tabular}{lllllll}
\hline $\begin{array}{l}\text { Sourceof } \\
\text { Variation }\end{array}$ & $\boldsymbol{S S}$ & $\boldsymbol{d f}$ & $\boldsymbol{M S}$ & $\boldsymbol{F}$ & $\boldsymbol{P}$-value & $\boldsymbol{F}$ crit \\
\hline Between Groups & 0.04240956 & 6 & 0.00706826 & 0.406337446 & 0.868493804 & 2.445259 \\
Within Groups & 0.48706135 & 28 & 0.01739505 & & & \\
& & & & & & \\
Total & 0.52947091 & 34 & & & & \\
\hline
\end{tabular}

The calculated p-value is 0.87 (approx.) which is greater than the critical value of 0.05 . It implies that the null hypothesis is accepted. So, it can be concluded that there is no significant difference in return among equity funds under Tier-II of NPS.

Hypothesis (2) H0: There is no significant difference in the return of the equity fund under Tier-II and NIFTY50

HI: There is a significant difference in the return of the equity fund under Tier-II and NIFTY50.

The calculated p-value is 0.47 (approx.) which is greater than the critical value of 0.05 . It implies that the null hypothesis is accepted. So, it can be concluded that there is no significant difference in return between equity fund Tier-II of NPS and Nifty50.

t-Test: Paired Two Sample for Means

\begin{tabular}{lll}
\hline & Nifty & Tier-II \\
\hline Mean & 18.99 & 17.29226667 \\
Variance & 188.01825 & 145.9401834 \\
Observations & 5 & 5 \\
Pearson Correlation & 0.940223322 & \\
Hypothesized Mean Difference & 0 & \\
df & 4 & \\
t Stat & 0.800936824 & \\
P(T<=t) one-tail & 0.234021259 & \\
t Critical one-tail & 2.131846786 & \\
P $(T<=t)$ two-tail & 0.468042518 & \\
t Critical two-tail & 2.776445105 & \\
\hline
\end{tabular}

Hypothesis (3) H0: There is no significant difference in risk among equity funds Under Tier-II. HI: There is a significant difference in risk among equity funds Under Tier-II.

The calculated p-value is 0.605 (approx.) which is greater than the critical value of 0.05 . It implies that the null hypothesis is accepted. So, it can be concluded that there is no significant difference in risk among equity funds under Tier-II of NPS.

ANOVA

\begin{tabular}{lllllll}
\hline $\begin{array}{l}\text { Sourceof } \\
\text { Variation }\end{array}$ & SS & df & MS & F & P-value & F crit \\
\hline Between Groups & 0.000253 & 6 & 0.0000421 & 0.76548 & 0.605181 & 2.572711641 \\
Within Groups & 0.001155 & 21 & 0.00005501 & & & \\
& & & & & & \\
Total & 0.001408 & 27 & & & & \\
\hline
\end{tabular}

Hypothesis (4) H0: There is no significant difference in the risk of the equity fund under Tier-II and NIFTY50 HI: There is a significant difference in the risk of the equity fund under Tier-II and NIFTY50. 
The calculated p-value is 0.113 (approx.) which is greater than the critical value of 0.05 . It implies that the null hypothesis is accepted. So, it can be concluded that there is no significant difference in risk between the equity fund under Tier-II and Nifty50.

t-Test: Paired Two Sample for Means

\begin{tabular}{lll}
\hline & Nifty50 & Fund \\
\hline Mean & 1.032 & 1.177667 \\
Variance & 0.28922 & 0.334248 \\
Observations & 5 & 5 \\
Pearson Correlation & 0.960984187 & \\
Hypothesized Mean Difference & 0 & \\
df & 4 & \\
t Stat & -2.024330828 & \\
P(T<=t) one-tail & 0.056469621 & \\
t Critical one-tail & 2.131846786 & \\
P $(T<=t)$ two-tail & 0.112939241 & \\
t Critical two-tail & 2.776445105 & \\
\hline
\end{tabular}

\section{CONCLUSION}

From the above analysis and discussion, it is concluded that the performance of different equity funds under Tier-II of the National Pension System (NPS) differs from each other. It may happen due to the strategy framed by the pension fund managers. The effective strategy itself helps pension fund managers to get more returns than the market. As per the study, LIC PF and ICICI PF are the best performer during the study period. It can earn a higher return than the market return whereas other funds are unable to gain more than the market return. The performance of SBI PF is poor among other equity funds under Tier-II of NPS during the study period. In term of risk, LIC PF is the higher risky equity fund and UIT PF is the lowest risky equity fund under Tier-II of NPS. It can be said that investors need to be high-risk taker to invest in that LIC PF. Other equity funds of Tier-II have lower returns than the market, but it is also necessary to see that the risk in these funds is also less than the market risk. Through the risk analysis during said period of time, it is found that the ability to observe risk differs in equity funds under Tier-II of NPS. The main reason for this being a voluntary account of Tier -II. And with this, there is no lock-in period in this account which is mostly used for a short-term purpose by investors. Whereas, investment is considered to be long-term to get higher returns from equity funds. So, it can be said that investment in equity funds under Tier-II of National Pension Funds for the short-term may not be a perfect decision for the investors. In the recent decision of the government, Tier-II offers a lock-in period for 3 years with tax benefit. This decision may be effective to attract investors to invest in equity funds of Tier-II under NPS

\section{REFERENCES}

1. Chander Harish, 2017. "A Comparative Study of Pension Fund Managers Operating Scheme - C (Tier-II) of National Pension System." International Journal of Research in Finance and Marketing (2017): 198-212, Vol. 7 Issue 6, June - 2017.

2. D. ASAMOAH OWUSU, S. K. APPIAH, A.Y. OMARI-SASU, G.S. OWUSU, 2016. "Pension Fund Asset Allocation under the Markowitz Model: A Case of the National Pension Scheme in Ghana"." International Journal of Scientific \& Engineering Research (2016): 86-91. Applied Mathematics 2016, 6(4): 86-91, DOI: 10.5923/j.am.20160604.04, http://journal.sapub.org.

3. Gaguk Apriyanto, Eko Ganis Sukoharsono, Gugus Irianto, Erwin Saraswat, 2016. "A CRITICAL ANALYSIS ON PENSION FUND PERFORMANCE: AN ASSESSMENT IN THE PERSPECTIVE OF POLITICAL ECONOMY OF ACCOUNTING." International Journal of Business and Management (2016): 141-152. Vol. 11, No. 2; 2016, ISSN 1833-3850 E-ISSN 1833-8119.

4. Goyal K Anil, Madan Tamanna, 2018. "'A COMPARATIVE STUDY OF RETURNS OF SELECTED MUTUAL FUNDS SCHEMES WITH NIFTY50."." VSRD International Journal of Business and Management Research (2018): 216-220. Vol. VIII Issue VI June 2018, e-ISSN: 2231-248X, p-ISSN: 2319-2194 @ VSRD International Journals: www.vsrdjournals.com. 
5. Gupta Sen Subhro, gargkomal and Garg Komal, 2017. "An Empirical Study of National Pension Scheme with respect." International Journal of Engineering Technology Science and Research (2017): 527-534. Volume 4, Issue 10, ISSN 2394 - 3386.

6. Hussein Abedi Shamsabad, Mohammad Nourani Dargiri, Devinaga Rasiah. "A Review Study of Risk-Return Relationship and Performance Measures Comparing." Australian Journal of Basic and Applied Sciences (2012): 14-22. Australian Journal of Basic and Applied Sciences, 6(12): 14-22, 2012, ISSN 1991-8178.

7. Meneka, K Seethal \& B, 2018. "Evolution of National Pension Scheme for retirement planning." International Journal of Economics Commerce and Research (IJECR) (2018): 154-159. ISSN (P): 2250-0006; ISSN (E): 23194472.

8. S.Ramesh, 2017. "Pension Plans : Awareness Among private sectors -An Empirical study." Parikalapana - KIIT Journal of Management. (2017): 67-78.

9. Samuel G. Njeri, Abel G. Anyieni, 2018. "EVALUATION OF STRATEGIC FIT COMPONENTS AND INFLUENCE ON ORGANIZATION PERFORMANCE: CASE OF RETIREMENT BENEFITS AUTHORITY IN KENYA PENSION SECTOR." International Journal of Research in Social Sciences (2018): 211-220. Volume : 8, Issue : 8, Online ISSN : 2249-2496.

10. Shallu Saini, shimar Deepika, 2017. "Comparative study of Mutual Fund Scheme and New Pension System." International Journal of Academic Research and Development, 2(5) (2017): 258-262.

11. M. K. Kurmi, B. Kapasi, and R.K. Paswan (2020), "Relative Assessment of The Performance of Various Schemes of National Pension Scheme in India: An Empirical Analysis" Pura Kala, Vol-31, Issue-56, June 2000 